\title{
Developing an interpretation of collective beliefs in language teacher cognition research
}

\section{Neil England, University of Technology Sydney}

Language teacher cognition research is understood as the investigation of "what language teachers think, know and believe" (Borg, 2006, p. 1) and, in most cases, how it relates to teachers' classroom practices. The most common unit of analysis in this type of research is the individual (Borg, 2006). This work is normally informed by broader constructs of teacher knowledge in general, as opposed to the specialised knowledge of language teachers. One such construct is personal practical knowledge (Clandinin \& Connelly, 1986; Golombok, 1998). Personal practical knowledge is understood to be experiential, situated and storied, embedded in daily classroom practices and constructed and reconstructed through personal narratives of life and classroom experiences. As such, it is usually seen as idiosyncratic. Most studies of personal practical knowledge, therefore, use the individual as the unit of analysis on the assumption that "each person's knowledge cannot be codified across individuals without damaging important nuances of meaning" (Carter, 1990, p. 304).

However, in line with the sociocultural turn in thinking about teacher knowledge and teacher learning (Johnson 2006, 2009), with its emphasis on learning within a community of practice (Wenger, 1998), there is recognition of the need for a collective perspective in qualitative teacher cognition research (Schulman \& Schulman. 2004). Such a perspective identifies shared beliefs and classroom practices of groups of language teachers working in the same context or similar contexts. It represents a shift from "a concern with individual teachers to a conception of teachers learning and developing within a broader context of community, institution, polity, and profession" (Schulman \& Schulman, 2004, pp. 267-269).

Borg (2003, 2006), in setting an agenda for language teacher cognition research, supports this shift in perspective, or at least the addition of a collective perspective alongside the traditional focus on the individual. The problem this article addresses is that language teacher cognition researchers wishing to adopt a collective perspective are provided with little methodological direction. These researchers are likely to benefit from descriptive and frank reflexive accounts of the processes and tools others have used in studies which adopted a collective perspective. As a contribution to this literature, in this article I describe and reflect on the processes and tools I used in a study that developed an interpretation of the collective epistemological beliefs of a group of Indonesian language teacher educators.

I work on the assumption that language teacher educator cognition research can be viewed as either a niche within language teacher cognition research or as a parallel field. This assumption is based on two understandings. The first understanding is that both language teacher educators and language 
teachers are classroom practitioners whose pedagogical decisions and instructional practices are shaped, although not entirely determined, by a network of normally tacitly held beliefs, developed from a range of sources and mediated by a range of contextual factors (Barnard \& Burns, 2012; Borg, 2006; Freeman, 2002). The second understanding is that, given these parallels, language teacher educator cognition researchers and language teacher cognition researchers share many typical data collection methods. In this article I point out (1) which of the processes and which of the tools I used in my study of language teacher educator collective beliefs could apply to research involving language teachers, (2) where adaption would be necessary, and (3) what adaptations could be considered. The ideas I present apply most directly to intercultural research contexts, in which issues of language, power and role expectations are normally heightened.

\section{Overview of my study}

My experience of developing an interpretation of collective beliefs was through my study of the epistemology of practice of the five language teacher educators and the three trainers-in-training, who, at the time, made up the English Department of an Indonesian Ministry of National Education language teacher education center in Jakarta. The center provides intensive in-service education and training (INSET) for Indonesian state sector primary and secondary school foreign language teachers.

The data were collected from rounds of individual- and group-level dialogue (primarily in English) at the Jakarta center, followed by the observation of, and post-observation dialogue about, INSET sessions in a provincial Indonesian city. At the request of the Director of the Jakarta center, I engaged with the language teacher educators and the trainers-in-training as separate groups, and so kept them separate in my analysis. In this article, the reference to my study is in relation to (1) my primary research question, What are the participants' beliefs about the epistemology of INSET for Indonesian state sector primary and secondary school teachers of English?; (2) the language teacher educators; and (3) the interpretation I developed in the field; that is, while in Jakarta.

\section{The stages in the development of my interpretation of collective beliefs}

There were three stages in the development of my interpretation of the language teacher educators' collective epistemological beliefs: (1) collecting the data through recorded dialogues with the participants and engaging with the data immediately; (2) preparing a written summary of my interpretation, given to the group; and (3) discussing the written summary with the group.

\section{Collecting and engaging with the data}

The data informing my written summary interpretation of the collective epistemological beliefs of the language teacher educators came from four rounds of recorded dialogue: two group-level dialogues, followed by two individual-level dialogues. The purpose of the first group-level dialogue was to develop my understanding of the context and nature of the language teacher educators' work, as well 
as to develop rapport and diagnose any issues arising from the use of English as the medium of communication. The second group-level dialogue explored, in broad terms, the topics of language learning and teaching, language teacher learning and models of language teacher education. The purpose of the first individual-level dialogue was for me to understand individual differences in career history and current professional roles and to establish a shared language for continued dialogue about the epistemology of INSET. The second individual-level dialogue was the co-construction of beliefs about the epistemology of INSET in the Indonesian state sector context.

I did not use any mediational tools in the first group-level dialogue, in an effort to keep the dialogue natural and thereby build rapport. In the second group-level dialogue I used pieces of published English language teaching material (from a widely used course book) and published second language teacher education material. I made this choice on the assumption that dialogue centered on the concrete methodological detail of language teaching and language teacher education, as opposed to dialogue centered on abstract categories of knowledge, is more likely to facilitate the co-construction of the participants' tacitly held beliefs (Borg, 2015).

In these two group-level dialogues, allowing any shared understandings to emerge required careful discourse management. Although the language teacher educators were ostensibly of equal status, it soon became clear that turn-taking in the group was influenced by factors such as age, seniority and administrative role within the Jakarta centre, level of professional engagement with the wider language teacher education community, confidence in oral English and personality. Gender did not appear to be a factor. My challenge was to distribute turn-taking to establish shared understandings, while, at the same time, endeavouring to keep the talk natural and to encourage positive participation in it.

After a group member expressed a particular understanding of language learning and teaching, teacher learning or language teacher education, either in a universal sense or in the Indonesian context, I asked for comment from others in the group. I did this by using questions such as:

Do you agree with Siti about the value of models?

Do you think Agus is right in saying that teachers generally don't like theory?

These questions were normally directed to the remainder of the group in general. I did not insist that each participant respond individually and at length to a comment from another group member. I reasoned this would have resulted in unnatural discourse, and would have been potentially threatening, thereby affecting my rapport with the group. 
On reflection, it would have been better research practice to provide more thinking time for considered individual responses, and to provide scaffolding language, first modelled and then given on a handout, for those less confident in spoken English. Examples of this language are given below:

I agree with Tarto. This is important in our work + Why it is important

I think this is generally the case + Examples from your experience

I'm not sure this is always the case + Examples of when it is not the case

I don't really agree with Poppy here + How your experience is different

The mediational tool for the first part of the first individual-level dialogue, which focused on individual differences in career history and current professional roles, was an autobiographical fact sheet. I asked each participant to complete this in advance, recording what, when, where and how long details about their foreign language learning experience, their language teaching experience and their language teacher education experience. The second half of the first individual-level dialogue established a shared language for continued dialogue about the epistemology of INSET, using terms such as external knowledge, personal knowledge and context knowledge. Here I used published second language teacher education material in which there was distinct and concrete focus on each of these forms of teacher knowledge. In the second individual-level dialogue the co-construction of beliefs about the epistemology of INSET in the Indonesian state sector context was mediated by five scenarios - 'brief descriptions of hypothetical instructional events" (Borg, 2006, p. 192) - which I wrote about the Indonesian INSET classroom, each centering on some questioning of the value attached to a particular form of teacher knowledge.

Following directives from within mainstream teacher cognition research (Verloop, van Dreil \& Meijer, 2001), I did not make an a priori assumption that there was a set of collective beliefs among the group; this needed to be established empirically. However, the use of standardised mediational tools in the two rounds of individual-level dialogues aided the identification of patterns in the ideas expressed. These tools facilitated the co-construction of beliefs about specific dimensions of the language teacher educators' work, as opposed to diffuse generic beliefs within which meaningful patterns would be more difficult to identify. The process of co-constructing specific epistemological beliefs, and later identifying collective features, was aided by the use of a shared language for different forms of teacher knowledge. This supports the case made in the literature on dialogic inquiry and dialogic modes of professional learning (Freeman, 2002; Johnson, 2009; Wells, 1999; Wenger, 1998) of the importance of a negotiated shared understanding of key terms in the description and justification of professional practices. 
All the dialogues were recorded on a compact digital recorder. I listened to the recordings made on any one day at the end of that day and used a research journal (Borg, 2001) to note emerging collective and idiosyncratic patterns in the data. I also used the recordings to reflect on my management of the discourse, particularly in terms of allowing both idiosyncratic and collective beliefs to be expressed. I structured these reflections through the act of writing about them in the research journal and, following Borg (2001), used them as reflexive data in the full report on my study.

In studies of the collective beliefs of groups of language teachers, researchers could follow similar processes using similar mediational tools, as suggested in Table 1.

Table 1

Suggested data collection activities for a qualitative study of language teacher collective beliefs

\begin{tabular}{|c|c|l|l|}
\hline \multicolumn{2}{|c|}{ Dialogue form } & \multicolumn{1}{|c|}{ Purpose } & \multicolumn{1}{c|}{ Mediational tools } \\
\hline 1 & Group-level & $\begin{array}{l}\text { Understand teachers professional context; } \\
\text { develop rapport and diagnose language-related } \\
\text { issues. }\end{array}$ & $\begin{array}{l}\text { None, apart from perhaps literature about the } \\
\text { teachers' institution(s). }\end{array}$ \\
\hline 2 & Group-level & $\begin{array}{l}\text { Explore in broad terms issues of language } \\
\text { learning and teaching. }\end{array}$ & $\begin{array}{l}\text { Published language teaching material, such } \\
\text { as a unit from a course book. }\end{array}$ \\
\hline Individual-level & $\begin{array}{l}\text { Appreciate individual differences. } \\
\text { Establish anstruction of spared language for co- } \\
\text { language learning and teaching. }\end{array}$ & $\begin{array}{l}\text { Autobiographical fact sheet. } \\
\text { Published language teaching material, such } \\
\text { as a unit from a course book. }\end{array}$ \\
\hline 4 & Individual-level & $\begin{array}{l}\text { Co-construct specific beliefs about language } \\
\text { learning and teaching. }\end{array}$ & $\begin{array}{l}\text { Researcher-designed scenarios of teaching } \\
\text { dilemmas in the language classroom (among } \\
\text { other possible tools). }\end{array}$ \\
\hline
\end{tabular}

Dialogue 1 and Dialogue 2 could be combined. With larger groups, and in cases where it is not possible or practical to have all the participants together at one time, these dialogues could be conducted in small groups. If the choice is made to form small groups, there is a case for establishing a shared language at this point. The nature of this shared language will depend on the specific beliefs in focus. For example, the co-construction of beliefs about teaching grammar could be based on a negotiated understanding of terms from the Second Language Acquisition (SLA) literature such as input, noticing, interaction and output. Dialogue 4 could be extended by using a range of other approaches, such as those presented by Borg (2015) in his account of researching L2 teachers' beliefs. As Borg notes, dialogue conducted in reference to the teachers' observed classroom practices is particularly desirable.

\section{Preparing a written summary interpretation of collective beliefs}


Over a five-day period following the last individual-level dialogue, I listened again to all the recorded dialogues, read the interpretative comments in my research journal, questioned and retracted some of these comments, added detail to and refined others, and added new interpretative comments. The outcome of this process was a one-page written summary interpretation of the language teacher educators' collective epistemological beliefs. The audience for this document was the language teacher educators themselves.

The document was presented under headings that featured the shared language established in Dialogue 3 (External knowledge, Practical knowledge, Context knowledge). Under each heading were sentences that expressed a particular dimension of the interpretation relevant to that heading. These sentences were numbered for efficient reference in later dialogue. Where possible, they were sentences of one clause. An illustrative excerpt from the document is given below:

\section{Practical knowledge}

1. Teachers' practical knowledge must be respected in the INSET classroom.

2. Reflection on, and the sharing of, current practical knowledge alone is not enough for teacher learning; teachers need to be exposed to external knowledge.

3. Teachers cannot internalise external knowledge if it is dissociated from practical knowledge.

In the case of a written summary interpretation of language teacher collective beliefs, the same analytical and formatting principles could apply. However, different headings would obviously be required. These headings would depend on the focus of the study and the shared language which has been established for such a focus. For example, drawing on the example in the previous section, the headings for a study of beliefs about teaching grammar could use the SLA research-based terms Input, Noticing, Interaction and Output.

A variation to the suggested document format would be to provide illustrative quotes for each numbered sentence, using the participants' own words, taken from the recorded (but at this stage not yet transcribed) dialogues. This is likely to aid the participants' comprehension of abstract ideas. Such a consideration is especially relevant in an intercultural research context, where the language of communication between the researcher and the participants may be the researcher's first language, not the participants'.

\section{Discussing the written summary interpretation with the participants}

I gave the language teacher educators the written summary interpretation of their collective epistemological beliefs to read two days before a final group-level meeting with them. This meeting sought respondent validation (Borg, 2012; Silverman, 2010) of the interpretation. In a written statement accompanying the summary interpretation document, I explained that the purpose of the final group meeting was for the participants to comment on what in the document was an accurate or 
inaccurate representation of the ideas expressed in Dialogues 1 to 4 (see Table 1) and what was or was not a belief held individually. At the start of the meeting I provided the following language scaffolding on a separate sheet and gave examples of how the patterns could be used to produce full statements:

\author{
This is what I/we said when we talked about ...+ Details \\ This is not what I/we said when we talked about ... + What you actually said \\ I agree with Point [2] under [External knowledge]. + Details \\ I don't agree with Point [3] under [Practical knowledge]. + Your view
}

I was aware from the literature (Bloor, 1997; Borg, 2012; Silverman, 2010) that respondent validation does not ensure the validation of research findings. I was also conscious of social and linguistic factors within the intercultural research setting. I anticipated that the status and power accorded to me as a foreign academic researcher would have an impact on the group's willingness to provide frank feedback, and I was aware of the role of language within this power relationship. Within dialogue in English, I held considerable power as the native speaker.

However, the group's comprehensive comments on my interpretation suggested that we - researcher and research participants - had established and maintained a positive and productive 'culture of dealing' (Holliday, 2007) in this research setting. The group confirmed most of the statements in the document as accurate, suggested some should be foregrounded as 'core' beliefs (Pajares, 1992; Phipps $\&$ Borg, 2009) and others placed under a different heading, and added statements to provide a more complete picture of their epistemology of practice in the Indonesian state sector context. Two of the language teacher educators commented that some of the statements were of beliefs that they held yet were not normally required to act on in the INSET classroom as a result of the particular curriculum areas they normally taught.

The form of respondent validation presented here, and the concessions attached to it, could apply to research involving language teachers. With a larger group and where it is not possible or practical to bring all the participants together at one time, dialogue in smaller groups would achieve the same purpose. Again where possible, and with sensitivity to the time demands on them, the language teachers could be asked to meet on their own before the meeting with the researcher to discuss the interpretation of their collective beliefs. In intercultural contexts where the language teachers share a first language different from the language used in communication with the researcher, the discussion could be in this first language.

\title{
Conclusion
}


In this article I have provided a descriptive and reflexive account of the processes and tools I used in a study that developed an interpretation of the collective epistemological beliefs of a group of Indonesian language teacher educators. I have also discussed the possible application and adaptation of these processes and tools in studies investigating the collective beliefs of language teachers, especially in intercultural research contexts. The discussion has drawn attention to (1) issues of language and power, (2) discourse management, (3) the need for a shared understanding of key terms, and (4) the value of standardised mediational tools.

The discussion has also supported Borg's (2006) point that in language teacher cognition research “...choices will often need to be made not just on methodological grounds but also with an awareness of what is practically feasible, acceptable and permissible in a particular context under study" (p. 280). With so little methodological direction available on developing an interpretation of collective beliefs, we need stories from language teacher cognition researchers about their experiences in conducting studies featuring this type of interpretation. These stories need to be set in different research contexts and need to describe and justify the choices the researchers made.

\section{References}

Barnard, R., \& Burns, A. (2012). Introduction. In R. Barnard \& A. Burns (Eds.), Researching language teacher cognition and practice: International case studies (pp. 1-10). Bristol, UK: Multilingual Matters.

Bloor, M. (1997). Techniques of validation in qualitative research: A critical commentary. In D. Miller \& R. Dingwall (Eds.), Context and method in qualitative research (pp. 37-50). London: Sage.

Borg, S. (2001). The research journal: A tool for promoting and understanding researcher development. Language Teaching Research, 5(2), 156-177. http://dx.doi.org/10.1191/136216801678766895

Borg, S. (2003). Teacher cognition in language teaching: A review of research into what language teachers think, know, believe and do. Language Teaching, 36(2), 81-109. http://dx.doi.org/10.1017/S0261444803001903

Borg, S. (2006). Teacher cognition and language education. London: Continuum.

Borg, S. (2012). Current approaches to language teacher cognition research: A methodological analysis. In R. Barnard \& A. Burns (Eds.), Researching language teacher cognition and practice: International case studies (pp. 11-29). Bristol, UK: Multilingual Matters. 
Borg, S. (2015). Researching teachers' beliefs. In B. Paltridge \& A. Phakiti (Eds.), Research methods in applied linguistics (pp. 487-504). London \& New York: Bloomsbury.

Carter, K. (1990). Teachers' knowledge and learning to teach. In W. Houston (Ed.), Handbook of research on teacher education (pp. 291-310). New York: Macmillan.

Clandinin, D., \& Connelly, F. (1986). Rhythms in teaching: The narrative study of teachers' personal practical knowledge of classrooms. Teaching and Teacher Education, 2(4), 377-387. http://dx.doi.org/10.1016/0742-051X(86)90030-2

Freeman, D. (2002). The hidden side of the work: Teacher knowledge and learning to teach. Language Teaching, 35(1), 1-13.

Golombek, P. (1998). A study of language teachers' personal practical knowledge. TESOL Quarterly, 32(3), 447-464. http://dx.doi.org/10.2307/3588117

Johnson, K. (2006). The sociocultural turn and its challenges for second language teacher education. TESOL Quarterly, 4O(1), 235-257. http://dx.doi.org/10.2307/40264518

Johnson, K. (2009). Second language teacher education: A sociocultural perspective. New York: Routledge.

Pajeres, M.F. (1992). Teachers' beliefs and educational research: Cleaning up a messy construct. Review of Educational Research, 62(3), 307-332. http://dx.doi.org/10.3102/00346543062003307

Phipps, S., \& Borg, S. (2009). Exploring tensions between teachers' grammar teaching beliefs and practices. System, 37(3), 380-390. http://dx.doi.org/10.1016/j.system.2009.03.002

Schulman, L., \& Schulman, J. (2004). How and what teachers learn: A shifting perspective. Journal of Curriculum Studies, 36(2), 257-271. http://dx.doi.org/10.1080/0022027032000148298

Silvermann, D. (2010). Doing qualitative research ( $3^{\text {rd }}$ ed.). Los Angeles: Sage.

Verloop, N., van Driel, J., \& Meijer, P. (2001). Teacher knowledge and the knowledge base of teaching. International Journal of Educational Research, 35(5), 441-461. http://dx.doi.org/10.1016/S0883-0355(02)00003-4

Wells, G. (1999). Dialogic inquiry: Toward a sociocultural practice and theory of education. Cambridge: Cambridge University Press. Wenger, E. (1998). Communities of practice: Learning, meaning and identity. Cambridge: Cambridge University Press. 
(3636 words, including references)

\section{The author}

Neil England is a lecturer in the School of International Studies, University of Technology Sydney. His research interests are in language teacher and language teacher educator cognition, second language teacher education and curriculum development in language teaching. 